\title{
Pengaruh Profitabilitas, Solvabilitas, dan Opini Audit terhadap Au- dit Delay Dimoderasi oleh Ukuran Perusahaan
}

\author{
Putri Febisianigrum \\ Fakultas Ekonomi dan Bisnis, Universitas Budi Luhur \\ putrifebisia@gmail.com \\ Rinny Meidiyustiani \\ Fakultas Ekonomi dan Bisnis, Universitas Budi Luhur \\ rinny.meidiyustiani@budiuhur.ac.id
}

(Diterima: 12-Juni-2020; dipublikasikan: 31-Juli-2020)

\begin{abstract}
This study aimed to analyze the influence of profitability, solvency, and auditor's opinion set on audit delay, and to analyze the size of company in moderating the effect of profitability, solvency, and auditor's opinion set to audit delay. The population in this study is mining companies listed on Indonesia Stock Exchange period 2012-2017 by using purposive sampling technique and obtained a sample of study as many as 32 companies. The analysis has been carried out by using multiple regression analysis and moderated regression analysis. The result of this study shows that the partial profitability has negative effect to audit delay, solvency and auditor's opinion has not effect to audit delay, the size of company cannot moderate the effect of profitability set to the audit delay, solvency can moderate the effect of profitability set to the audit delay and auditor's opinion cannot moderate the effect of profitability set to the audit delay.
\end{abstract}

Keywords: Profitability; Solvency; Auditor's opinion; Audit delay; and the size of company

\begin{abstract}
Abstrak
Penelitian ini bertujuan untuk menganalisis pengaruh profitabilitas, solvabilitas, dan opini audit terhadap audit delay, serta untuk menganalisis ukuran perusahaan dalam memoderasi pengaruh profitabilitas, solvabilitas, dan opini audit. Populasi dalam penelitian ini adalah perusahaan pertambangan yang terdaftar di Bursa Efek Indonesia periode 2012-2017 dengan menggunakan teknik purposive sampling diperoleh sampel penelitian sebanyak 32 perusahaan. Teknik analisis yang digunakan adalah regresi linear berganda dan moderated regression analysis. Hasil penelitian ini menunjukkan bahwa secara parsial profitabilitas berpengaruh negatif terhadap audit delay, solvabilitas dan opini audit tidak berpengaruh terhadap audit delay, ukuran perusahaan tidak mampu memoderasi pengaruh hubungan antara profitabilitas terhadap audit delay, ukuran perusahaan mampu memoderasi pengaruh hubungan antara solvabilitas terhadap audit delay, dan ukuran perusahaan tidak mampu memoderasi pengaruh hubungan antara solvabilitas terhadap audit delay.
\end{abstract}

Kata Kunci: Profitabilitas; Solvabilitas; Opini audit; Audit delay; dan ukuran perusahaan 


\section{PENDAHULUAN}

Di era globalisasi ini, perusahaan go public semakin meningkat dengan menjaga pertumbuhan ekonomi perusahaannya. Suatu perusahaan dapat menarik investor untuk menanamkan modalnya dengan wajib melaporkan laporan keuangan. Laporan keuangan merupakan suatu hal yang paling penting dalam suatu perusahaan. Setiap perusahaan yang sudah terdaftar di Bursa Efek Indonesia, wajib untuk melaporkan laporan keuangan secara berkala pada Bursa Efek Indonesia.

Laporan keuangan perusahaan go public harus dilaporkan setiap tahunnya. Berdasarkan peraturan Otoritas Jasa Keuangan (OJK) Nomor 29/POKJ.04/2016 menyatakan bahwa emiten atau perusahaan publik wajib menyampaikan laporan tahunan kepada Otoritas Jasa Keuangan paling lambat pada akhir bulan keempat setelah tahun buku berakhir (120 Hari). Ketidaktepatan waktu atas pelaporan laporan keuangan yang dilakukan perusahaan akan dikenakan sanksi dalam bentuk peringatan tertulis, denda, pembatasan atau pembekuan kegiatan usaha, pencabutan izin usaha, pembatalan persetujuan dan pembatalan pendaftaran.

\section{Tabel 1 Jumlah Perusahaan Go Public yang Terlambat dalam Menyampaikan Laporan Keuangan Audit tahun 2012-2017}

\begin{tabular}{lc}
\hline Tahun & $\begin{array}{c}\text { Jumlah Perusahaan Go Public } \\
\text { yang Terlambat } \\
\text { Menyampaikan Laporan } \\
\text { Keuangan Audit }\end{array}$ \\
\hline 2012 & 52 perusahaan \\
2013 & 49 perusahaan \\
2014 & 52 perusahaan \\
2015 & 18 perusahaan \\
2016 & 17 perusahaan \\
2017 & 10 perusahaan \\
\hline
\end{tabular}

Sumber : www.idx.co.id

Fenomena yang terjadi selama 6 tahun terakhir ini membuktikan bahwa perusahaan go public masih ada yang terlambat dalam pelaporan laporan keuangan auditan. Namun demikian, masih banyak perusahaan go public lain yang menyampaikan laporan keuangannya sesuai prosedur dan tepat waktu dalam pelaporannya.

Terdapat fenomena yang terkait dengan audit delay yang terjadi di Indonesia. Berdasarkan pengumuman dari Bursa Efek Indonesia pada 2018 terdapat 10 perusahaan yang terlambat melaporkan laporan keuangan tahun 2017 dan belum membayar denda, delapan diantaranya merupakan perusahaan pertambangan yaitu PT. Apexindo Pratama Duta Tbk (APEX), PT. Bara Jaya Internasional Tbk (ATPK), PT. Borneo Lumbung Energi \& Metal Tbk (BORN), PT. Cakra Mineral Tbkn (CKRA), PT. Darma Henwa Tbk (DEWA), PT. Astrindo Nusantara Infrastruktur Tbk (BIPI), PT. Energi Mega Persada Tbk (ENRG), PT.Medco Energi Internasional Tbk (MEDC).

Berdasarkan fenomena yang telah diuraikan, perusahaan yang telat dalam penyampaian laporan audit merupakan tolok ukur yang dapat dilihat oleh pihak investor dalam menanamkan modalnya dan sebagai salah satu kriteria profesionalsime dari auditor (Eksandy, 2017).

Rentang waktu dalam proses audit dikenal dengan sebutan audit delay yang diukur dari tanggal penutupan tahun buku hingga tanggal ditandatanganinya laporan audit. Pentingnya audit delay suatu laporan keuangan menuntut auditor agar menyelesaikan pekerjaan lapangannya tepat waktu (Okalesa,2018).

Keterlambatan publikasi laporan keuangan dapat mengindikasikan adanya masalah dalam laporan keuangan perusahaan, karena memerlukan waktu yang lebih lama dalam penyelesaian audit. Menurut Arumsari dan Handayani (2017), lamanya waktu penyelesaian audit atas laporan keuangan ini dinamakan dengan audit delay.

Penyampaian laporan keuangan secara tepat waktu dapat menjadi daya tarik investor untuk menanamkan modalnya. Maka dari itu, perusahaan harus segara menyelesaikan laporan keuangan auditnya dan auditor yang ditunjuk dapat bekerja sesuai dengan standar sehingga tidak mengalami audit delay. Berdasarkan pengumuman dari Bursa Efek 
Indonesia, penyampaian laporan keuangan audit perusahaan pertambangan masih belum stabil dan cendurung naik turun bahkan belum membayar denda keterlambatan dari tahun sebelumnya pada periode 2012-2017, dapat dilihat pada gambar di bawah ini.

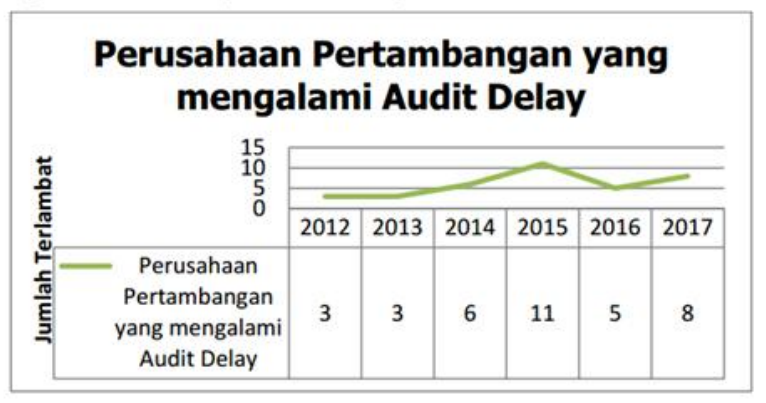

\section{Gambar 1 Grafik Audit Delay Tahun 2012- 2017}

Berdasarkan fenomena yang telah dijelaskan, peneliti memutuskan untuk meneliti pada Perusahaan Pertambangan yang terdaftar di Bursa Efek Indonesia (BEI) tahun 20122017. Pada tahun 2015 salah satu emiten terlambat dalam menyampaikan laporan keuangan auditnya yaitu PT. Bumi Resources Tbk (BUMI) milik Grup Bakrie menyatakan bahwa belum bisa melaporkan laporangan keuangan audit 2014 dikarenakan perseroan masih dalam perhitungan hutang (www.neraca.co.id). Tahun 2016 terdapat 18 emiten yang belum membayar denda keterlambatan dalam menyampaikan laporan keuangan audit 2015 yaitu PT. Borneo Lumbung Energi \& Metal Tbk (BORN), PT. Benakat Integra Tbk (BIPI),PT. Berau Cool Energy Tbk (BRAU), PT. Energi Mega Persada Tbk (ENRG), PT. Permata Prima Sakti Tbk (TGKA) dan PT. Grada Tujuh Buana dan sebagian sudah didelisting emitennya oleh Bursa Efek Indonesia (www.cnnindonesia.com).

Berdasarkan gambar 1 peneliti mengambil periode 2012-2017 sebanyak 6 tahun karena periode 2012-2017 menunjukan tingkat audit delay pada perusahaan pertambangan cenderung naik turun dalam melaporkan keuangannya.

Penelitian ini bertujuan untuk menganalisis pengaruh profitabilitas, solvabilitas, dan opini audit terhadap audit delay serta untuk menganalisis ukuran perusahaan dalam memoderasi pengaruh profitabilitas. solvabilitas, dan opini audit.

\section{Kajian Teori}

\section{Teori Keagenan}

Keterikatan antara teori keagenan dengan audit delay sangat erat, dikarenakan prinsipal dalam penelitian ini adalah perusahaan yang menggunakan jasa auditor independen untuk menyelesaikan laporan keuangan, sedangkan yang berperan sebagai agen adalah auditor. Hal ini menjadikan adanya dua keterikatan yang menghubungkan teori keagenan antara perusahaan dan auditor. Perusahaan berharap auditor akan menyelesaikan laporan keuangan tepat waktu, sehingga informasi yang disajikan dalam laporan keuangan menjadi berkualitas. (Atmojo dan Darsono, 2017).

\section{Teori Sinyal}

Menurut Dewi dan Wiratmaja (2017) Signal adalah tindakan yang diambil manajemen dalam memberikan arahan bagi investor dalam memandang prospek perusahaan. Manfaat utama teori ini adalah ketepatan waktu penyajian laporan keuangan kepada publik yang merupakan sinyal dari perusahaan akan adanya informasi yang bermanfaat kepada pihak investor (Panjaitan, 2017).

\section{Audit Delay}

Audit delay merupakan lamanya waktu penyelesaian audit yang diukur dari tanggal penutupan tahun buku hingga tanggal penyelesaian pekerjaan lapangan yang dilakukan auditor independen (Wiryakriyana dan Widhiyani,2017).

Audit Delay $=$ Tanggal Laporan Audit - Tanggal

\section{Profitabilitas}

Profitabilitas merupakan kemampuan perusahaan dalam memperoleh laba yang berhubungan dengan tingkat penjualan, total aktiva maupun modal sendiri (Fahmi, 2014:122). 


$$
\text { ROA }=\frac{\text { Laba Bersih Setelah Pajak x } 100 \%}{\text { Total Aset }}
$$

\section{Solvabilitas}

Solvabilitas adalah kemampuan perusahaan untuk memenuhi semua kewajibannya, baik kewajiban jangka pendek maupun jangka panjang (Suginam,2016).

$$
\mathrm{DER}=\frac{\text { Total Hutang }}{\text { Total Ekuitas }} \times 100 \%
$$

\section{Opini Audit}

Opini audit merupakan kesimpulan akhir auditor yang didapatkan dari proses audit berdasarkan bukti dan temuan (Arens et al, 2014).

Perusahaan yang Menerima Opini Wajar Tanpa Pengecualian $=1$

Perusahaan yang Menerima Opini Selain Wajar Tanpa Pengecualian $=0$

\section{Ukuran Perusahaan}

Ukuran perusahaan adalah suatu proporsi dimana dapat diklasifikasikan besar kecil perusahaan dengan berbagai cara antara lain dinyatakan dalam total aktiva, nilai pasar saham, dan lain-lain (Miradhi dan Juliarsa, 2016).

Ukuran Perusahaan = Ln (Total Ass et)

\section{Pengaruh Profitabilitas terhadap Audit De- lay}

Profitabilitas menggambarkan kemampuan perusahaan dalam menghasilkan laba, perusahaan yang memiliki profitabilitas tinggi dapat dikategorikan perusahaan baik karena tidak akan menunda penyampaian informasi tersebut. Jika tingkat profitabilitas yang dimiliki perusahaan semakin tinggi maka semakin pendek waktu yang dibutuhkan untuk menyelesaikan auditnya, sementara tingkat profitabilitas yang dimiliki perusahaan semakin rendah, auditor justru harus berhati-hati dalam melaksanakan proses audit laporan keuangan, sehingga membutuhkan waktu yang lama (Miradhi dan Juliarsa, 2016). Hal ini didukung oleh penelitian Dewi dan Wiratmaja (2017) yang menunjukan bahwa profitabilitas berpengaruh negatif terhadap audit delay.

$\mathrm{H}_{1}$ : Profitabilitas berpengaruh negatif terhadap audit delay

\section{Pengaruh Solvabilitas terhadap Audit De- lay}

Tingkat solvabilitas perusahaan yang tinggi akan membuat auditor lebih berhatihati untuk melakukan auditnya, karena hal ini dapat memicu resiko kerugian dari perusahaan itu sehingga menyebabkan audit delay semakin lama (Eksandy, 2017). Perusahaan dengan tingkat hutang yang tinggi memiliki risiko gagal bayar yang tinggi sehingga meningkatkan kehati-hatian auditor dalam melakukan audit atas utang dan kepemilikan aset perusahaan. Jadi, semakin tinggi rasio utang terhadap aset, semakin lama rentang waktu yang dibutuhkan untuk penyelesaian audit laporan keuangan tahunan (Karang, Yadnyana, dan Ramantha, 2015). Hal ini didukung oleh penelitian Ningsih dan Widhiyani (2015) yang menunjukkan bahwa solvabilitas berpengaruh positif terhadap audit delay.

$\mathrm{H}_{2}$ : Solvabilitas berpengaruh positif terhadap audit delay

\section{Pengaruh Opini Audit terhadap Audit De- lay}

Proses pemberian pendapat merupakan tahap akhir dalam proses audit. Perusahaan yang tidak menerima opini audit selain wajar tanpa pengecualian diperkirakan akan mengalami audit delay yang lebih panjang. Hal ini karena, perusahaan yang menerima opini tersebut dipandang memiliki bad news dalam perusahaannya. Hal ini didukung oleh penelitian Subawa dan Dwiana (2016) yang menunjukkan bahwa opini audit berpengaruh negatif terhadap audit delay. Berdasarkan uraian tersebut, maka dapat disusun hipotesis sebagai berikut:

$\mathrm{H}_{3}$ : Opini Audit berpengaruh negatif terhadap audit delay

\section{Ukuran Perusahaan mampu memoderasi pengaruh hubungan antara profitabilitas terhadap audit delay}

Ukuran perusahaan menggambarkan besar kecilnya perusahaan yang dapat dilihat dari total asset yang dimiliknya. Perusahaan yang memiliki profitabilitas tinggi akan semakin cepat proses auditnya. Ketika dengan adanya ukuran perusahaan yang besar maka 
proses auditnya akan semakin cepat karena perusahaan yang besar cenderung mampu menyelesaikan auditnya lebih cepat dibandingkan dengan perusahaan kecil karena memiliki pengendalian internal yang efektif, sehingga kesalahan atau salah saji dalam laporan keuangan rendah (Mulyantari dan Latrini,2017). Hal ini didukung oleh penelitian Miradhi dan Juliarsa (2016) yang menunjukkan bahwa pengaruh profitabilitas terhadap audit delay dapat dimoderasi oleh ukuran perusahaan. Berdasarkan uraian tersebut, maka dapat disusun hipotesis sebagai berikut:

$\mathrm{H}_{4}$ : Ukuran Perusahaan mampu memoderasi pengaruh hubungan antara profitabilitas terhadap audit delay

\section{Ukuran Perusahaan mampu memoderasi pengaruh hubungan antara solvabilitas ter- hadap audit delay}

Perusahaan yang besar cenderung memiliki sumber daya yang memadai serta teknologi yang canggih sehingga akan mempercepat proses auditnya. Perusahaan yang memiliki solvabilitas yang tinggi proses auditnya akan semakin lama karena auditor dalam melakukan audit atas hutang diperlukan kehati hatian. Ketika dengan adanya ukuran perusahaan yang besar maka proses auditnya akan semakin cepat karena perusahaan besar memiliki sumber daya yang memadai dan teknologi yang canggih sehingga dapat mempermudah pekerjaan auditor misalnya dalam pelaksanaan auditnya dibandingkan dengan perusahaan yang kecil. Hal ini didukung oleh penelitian Lapinayanti dan Budiartha (2018) yang menunjukan bahwa pengaruh solvabilitas terhadap audit delay dapat dimoderasi oleh ukuran perusahaan. Berdasarkan uraian tersebut, maka dapat disusun hipotesis sebagai berikut:

$\mathrm{H}_{5}$ : Ukuran Perusahaan mampu memoderasi pengaruh hubungan antara solvabilitas terhadap audit delay

Ukuran Perusahaan mampu memoderasi pengaruh hubungan antara opini audit terhadap audit delay

Ukuran perusahaan dilihat dari total asset yang dimiliki oleh perusahaan. Perusahaan yang tidak menerima opini selain wajar tanpa pengecualian diperkirakan akan mengalami audit delay yang panjang. Ketika dengan adanya ukuran perusahaan besar cenderung memiliki audit delay yang lebih pendek dibandingkan dengan perusahaan yang lebih kecil. Karena perusahaan besar diperhatikan oleh pihak investor, kreditor, dan masyarakat yang membutuhkan laporan keuangan untuk keputusan bisnisnya. Sehingga, perusahaan besar dituntut untuk melaporkan laporan keuangannya lebih cepat. Hal ini didukung oleh penelitian Subawa dan Dwiana (2016) yang menunjukkan bahwa pengaruh opini audit terhadap audit delay dapat dimoderasi oleh ukuran perusahaan Berdasarkan uraian tersebut, maka dapat dirumuskan hipotesis keempat sebagai berikut:

$\mathrm{H}_{6}$ : Ukuran Perusahaan mampu memoderasi pengaruh hubungan antara opini audit terhadap audit delay

Model Penelitian dapat dilihat pada gambar berikut:

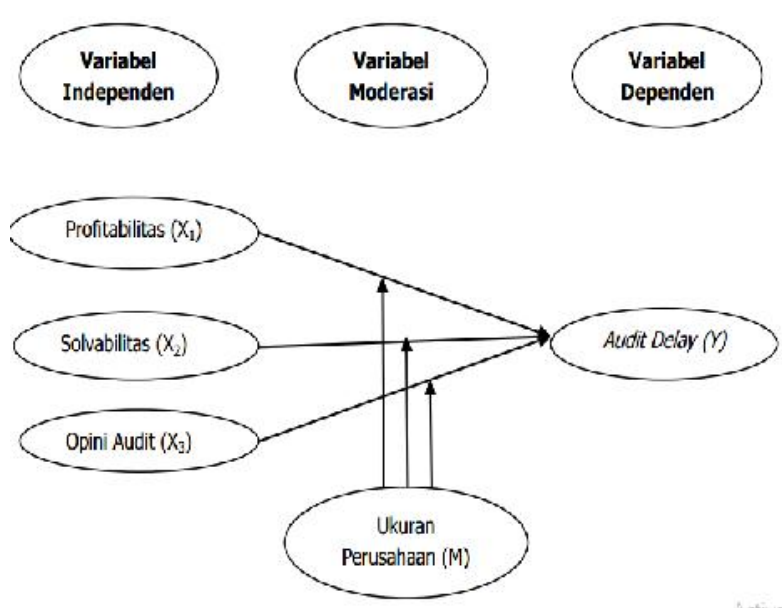

Gambar 2 Model Penelitian

\section{METODE PENELITIAN}

\section{Jenis Penelitian}

Metode yang digunakan dalam penelitian ini adalah metode penelitian kuantitatif. Menurut Sugiyono (2016:8) Metode penelitian kuantitatf dapat diartikan sebagai metode penelitian yang berlandaskan pada filsafat positivisme, digunakan untuk meneliti pada populasi atau sampel tertentu, pengumpulan data menggunakan instrumen penelitian, analisis data bersifat kuantitatif/statistik, dengan tujuan untuk menguji hipotesis yang telah ditetapkan. 


\section{Jenis Data}

Sumber data yang digunakan dalam penelitian ini adalah data sekunder berupa laporan keuangan perusahaan Pertambangan di website resmi Bursa Efek Indonesia (BEI) yaitu www.idx.co.id serta website perusahaan perusahaan yang menjadi objek penelitian.

\section{Pemilihan Sampel dan Pengumpulan Data}

Populasi dalam penelitian ini adalah perusahaan pertambangan yang terdaftar di Bursa Efek Indonesia (BEI) periode tahun 2012-2017 dengan total keseluruhan perusahaan yang terdaftar berjumlah 46 perusahaan. Perusahaan pertambangan merupakan perusahaan yang terdiri dari berbagai jenis sub sektor dan diharapkan akan mendapatkan sampel yang representatif serta hasil yang didapatkan akan lebih maksimal dengan penggunaan seluruh sub sektor tersebut.

\section{Tabel 2 Proses Pemilihan Sampel}

\begin{tabular}{llc}
\hline No & Proses Sampel Penelitian & Jumlah \\
\hline 1 & Perusahaan pertambangan yang & 46 \\
& terdaftar di Bursa Efek Indonesia & \\
& (BEI) pada tahun 2012-2017 \\
& Perusahaan pertambangan yang \\
& menerbitkan laporan keuangannya \\
& tidak secara berturut-turut selama \\
& tahun 2012-2017 \\
& Perusahaan pertambangan yang \\
memiliki ekuitas negatif pada ta- & \\
hun 2012-2017 \\
Jumlah perusahaan yang me- \\
menuhi proses sampel
\end{tabular}

\section{Definisi Operasional Variabel}

1. Variable dependen pada penelitian ini adalah audit delay. Menurut Wiryakriyana dan Widhiyani (2017) menyatakan bahwa audit delay merupakan lamanya waktu penyelesaian audit yang diukur dari tanggal penutupan tahun buku hingga tanggal penyelesaian pekerjaan lapangan yang dilakukan auditor independen.

Rumus:

Audit Delay $=$ Tanggal Laporan Audit - Tanggal Laporan Keuangan
2. Variabel Independen

a. Profitabilitas adalah kemampuan perusahaan dalam menghasilkan laba atau keuntungan selama periode tertentu pada tingkat penjualan, aset, dan modal saham tertentu (Okalesa,2018). Profitabilitas dapat dilihat dari tingkat rasio Return On Asset (ROA) (Dewi dan Wiratmaja, 2017). Rasio ini melihat sejauh kemampuan suatu perusahaan dengan menggunakan aktiva yang dimiliki untuk menghasilkan laba. Return on asset (ROA) dapat dirumuskan sebagai berikut

$$
\mathrm{ROA}=\frac{\text { Laba brsh Sth Pjk } \times 100 \%}{\text { Total Aset }}
$$

b. Solvabilitas adalah kemampuan perusahaan untuk memenuhi semua kewajibannya, baik kewajiban jangka pendek maupun jangka panjang. (Subawa dan Dwiana, 2016).

Rumus:

$$
\text { DER }=\frac{\text { Total Htg }}{\text { TotalE kuitas }} \times 100 \%
$$

c. Opini audit merupakan pernyataan atau pendapat yang diberikan oleh auditor agar perusahaan mengetahui mengenai kewajaran laporan keuangannya yang dievaluasi selama melaksanakan tugasnya (Putra dan Trisnawati,2016).

Perusahaan yang memperoleh opini audit $\mathrm{WTP}=1$

Perusahaan yang tidak memperoleh opini audit selain $\mathrm{WTP}=0$

3. Variabel moderasi

Ukuran perusahaan adalah suatu proporsi dimana dapat diklasifikasikan besar kecil perusahaan dengan berbagai cara antara lain dinyatakan dalam total aktiva, nilai pasar saham, dan lain-lain. (Eksandy, 2017)

Rumus Ukuran Perusahaan $=$ Ln $($ Total Asset 


\section{Teknik Pengujian Data}

Model analisa yang dipakai untuk memprediksi variabel dependen apabila nilai variabel independen mengalami kenaikan atau penurunan dan mengetahui arah hubungan antara variabel independen dengan variabel dependen apakah berhubungan positif dan negatif. Secara matematis model regresi linear berganda yang akan digunakan sebagai berikut:

\section{$\mathrm{AD}=\alpha+\beta 1 \mathrm{ROA}+\beta 2 \mathrm{DER}+\beta 3 \mathrm{OA}+\beta 4 \mathrm{UP}+$ $\beta 5 R O A * U P+\beta 5 D E R * U P+\beta 6 O A * U P+e$}

Keterangan:

$\begin{array}{ll}\mathrm{AD} & =\text { Audit Delay } \\ \alpha & =\text { Konstanta }\end{array}$

$\beta 1 \beta 2 \beta 3 \beta 4 \beta 5 \beta 6 \beta 7=$ Koefisien Regresi

ROA = Profitabilitas

DER $=$ Solvabilitas

OA = Opini Audit

UP = Ukuran Perusahaan

e $\quad=$ Error

\section{HASIL DAN PEMBAHASAN}

\section{Uji Asumsi Klasik}

Hasil uji One Sample KolmogorovSmirnov menunjukkan nilai signifikansi sebesar 0,552 yang lebih besar dari nilai signifikan 0,05 sehingga dapat dikatakan bahwa data residual pada model regresi berdistribusi secara normal. Terkait uji multikolinearitas, penelitian ini menggunakan variabel moderasi yang akan menyebabkan adanya multikolinearitas yang tinggi antara variabel independen dengan variabel interaksinya (Anshori, Sukoco dan Napitupulu, 2012). Sehingga diperoleh nilai VIF masing-masing variabel independen kurang dari 10 dan nilai tolerance masing-masing variabel independen lebih dari 0,1 dan dapat dikatakan bahwa antar variabel independen dalam model regresi terbebas dari masalah multikolinearitas. Selanjutnya uji heteroskedastisitas menggunakan hasil uji park menunjukkan nilai signifikansi untuk masing-masing variabel memiliki nilai signifikansi lebih dari 0,05. Sehingga dapat disimpulkan bahwa tidak terdapat masalah heteroskedastisitas pada model regresi. Pengujian yang terakhir yaitu uji autokorelasi dengan uji Durbin Watson (DW) yang menunjuk- kan nilai DW hitung sebesar 1,937 sehingga didapat DW berada diantara batas atas (dU) dan 4 dikurang batas atas (dU) atau dalam bentuk notasi notasi dU $<$ DW $<4-$ dU $(1,8459<1,937<2,1541)$, maka dapat dikatakan tidak ada masalah autokorelasi pada model regresi.

\section{Analisis Koefisien Determinasi}

Nilai Adjusted $R$ Square sebesar 0,191 atau 19,1\%. Koefisien ini menunjukkan bahwa pengaruh profitabilitas, solvabilitas, dan opini audit terhadap audit delay yang dimoderasi ukuran perusahaan adalah sebesar $19,1 \%$, sedangkan sisanya sebesar $80,9 \%$ dipengaruhi oleh variabel lain.

\section{Uji Kelayakan Model (Uji F)}

Tabel 3 Output Uji Kelayakan Model (Uji F)

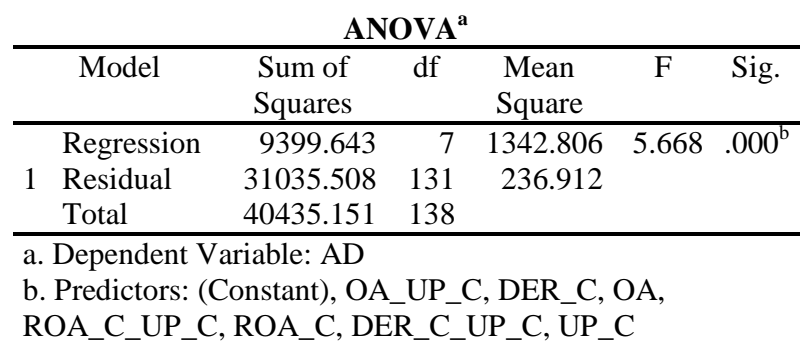

Berdasarkan tabel 3 dapat diketahui nilai $\mathrm{F}$ lebih besar dari tabel $\mathrm{F}(5,668>2,080)$ dan nilai Sig. lebih kecil dari $0,05(0,000<0,05)$ sehingga dapat disimpulkan bahwa $\mathrm{H}_{0}$ ditolak dan $\mathrm{H}_{1}$ diterima, artinya artinya model regresi layak digunakan dalam penelitian

\section{Tabel 4 Uji Hipotesis Output Hipotesis Penelitian (Uji t)}

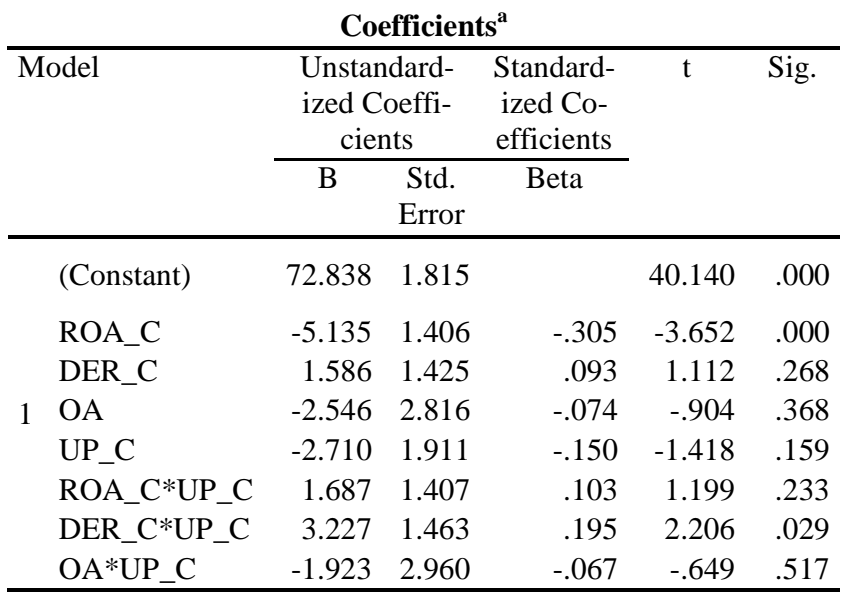

a. Dependent Variable: AD

Sumber : Hasil output spss versi 20.0 
Hasil regresi pada table 4 menunjukan bahwa variabel profitabilitas dan variabel interaksi solvabiltas dan ukuran perusahaan memiliki nilai signifikansi kurang dari 0,05 artinya profitabilitas berpengaruh negatif terhadap audit delay, dan ukuran perusahaan mampu memoderasi solvabilitas terhadap audit delay dengan arah positif. Sedangkan, variabel solvabilitas, variabel opini audit, variabel interaksi profitabiitas dan ukuran perusahaan, variabel interkasi opini audit dan ukuran perusahaan memiliki nilai signifikansi lebih dari 0,05 artinya solvabilitas dan opini audit tidak berpegaruh terhadap audit delay. Serta, ukuran perusahaan tidak mampu memoderasi pengaruh profitabilitas dan opini audit terhadap audit delay.

\section{Pengaruh Profitabilitas terhadap Audit De- lay}

Hasil penelitian ini menunjukan bahwa profitabilitas berpengaruh negatif terhadap audit delay. Hal ini berarti semakin tinggi profitabilitas maka semakin rendah audit delay yang dilakukan oleh perusahaan dan sebaliknya semakin rendah profitabilitas maka semakin tinggi audit delay yang dilakukan oleh perusahaan. Hal ini memicu perusahaan yang memiliki profitabilitas tinggi memiliki good news yang harus segera disampaikan maka perusahaan akan mempercepat proses auditnya dan tidak menunda penyampaian informasi keuangannya. Hasil penelitian ini konsisten dengan penelitian Miradhi dan Juliarsa (2016), Subawa dan Dwiana (2016), serta Dewi dan Wiratmaja (2017).

\section{Pengaruh Solvabilitas terhadap Audit De- lay}

Hasil penelitian ini menunjukan bahwa solvailitas tidak berpengaruh terhadap audit delay. Perusahaan yang memiliki solvabilitas tinggi maupun rendah tetap berupaya untuk melunasi kewajibannya dan tidak mempengaruhi audit delay. Hal ini dikarenakan, auditor dalam melaksanakan proses auditnya sesuai dengan standar profesional akuntan publik baik itu perusahaan memiliki total rasio solvabilitas tinggi ataupun rendah tidak akan memengaruhi proses penyelesaian audit laporan keuangan, karena auditor yang ditunjuk telah mempersiapkan perencanaan audit dan menyediakan waktu sesuai dengan kebutuhan jangka waktu untuk menyelesaikan proses auditnya. Hasil penelitian ini konsisten dengan penelitian Eksandy (2017).

\section{Pengaruh Opini Audit terhadap Audit De- lay}

Hasil penelitian ini menunjukan bahwa opini audit tidak berpengaruh terhadap audit delay. Opini yang dikeluarkan oleh auditor tidak mempengaruhi audit delay karena opini audit merupakan opini kewajaran laporan keuangan yang dimiliki perusahaan. Proses pemberiaan opini merupakan tahap akhir dalam proses audit, sehingga jenis opini audit apapun tidak akan mempengaruhi lamanya audit delay. Hal ini dikarenakan, auditor dituntut untuk melaksanakan tugas dan tanggung jawabnya dengan profesional sehingga apapun opini yang diberikan oleh auditor tidak akan mempengaruhi lamanya proses penyelesaian audit. Hasil penelitian ini konsisten dengan penelitian Miradhi dan Juliarsa (2016).

\section{Pengaruh Moderasi Ukuran Perusahaan terhadap Hubungan Antara Profitabilitas dan Audit Delay}

Hasil penelitian ini menunjukan bahwa ukuran perusahaan tidak mampu memoderasi profitabilitas terhadap audit delay. Besar kecilnya ukuran perusahaan tidak menentukan cepat atau lambatnya proses audit laporan keuangan baik pada perusahaan yang memiliki kemampuan menghasilkan laba yang tinggi maupun pada perusahaan yang memiliki kemampuan menghasilkan laba yang rendah. Hal ini dikarenakan, auditor akan mengerjakan prosedur auditnya sesuai dengan aturan yang berlaku, prosedur dan sudah memiliki perencanaan audit yang matang. Hasil penelitian ini konsisten dengan penelitian Subawa dan Dwiana (2016).

\section{Pengaruh Moderasi Ukuran Perusahaan terhadap Hubungan Antara Solvabilitas dan Audit Delay}

Hasil penelitian ini menunjukan bahwa ukuran perusahaan mampu memoderasi solvabilitas terhadap audit delay dengan arah positif. Perusahaan besar yang memiliki solvabili- 
tas yang tinggi dalam melakukan proses auditnya akan semakin lama. Hal ini dikarenakan pemeriksaan hutang dan perusahaan yang besar yang memerlukan waktu yang lebih lama dibandingkan perusahaan yang lebih kecil. Karena perusahaan yang besar memiliki kompleksitas perusahaan seperti kerumitan transaksi, banyaknya cabang perusahaan, dan transaksi menggunakan mata uang asing. Penelitian ini tidak konsisten dengan penelitian Subawa dan Dwiana (2016) yang menunjukan bahwa solvabilitas tidak mampu memoderasi ukuran perusahaan terhadap audit delay.

\section{Pengaruh Moderasi Ukuran Perusahaan terhadap Hubungan Antara Opini Audit dan Audit Delay}

Hasil penelitian ini menunjukan bahwa ukuran perusahaan tidak mampu memoderasi opini audit terhadap audit delay. Ketidakmampuan ukuran perusahaan dalam moderasi pengaruh opini audit terhadap audit delay dikarenakan baik perusahaan besar ataupun kecil auditor akan memberikan opininya sesuai dengan hasil akhir proses audit yang berdasarkan laporan keuangan beserta buktibukti yang dikumpulkan yang memerlukan waktu dalam proses auditnya. Hal ini dikarenakan ukuran perusahaan tidak mempengaruhi opini yang dikeluarkan karena auditor telah bekerja sesuai dalam standar professional akuntan publik. Hasil penelitian ini konsisten dengan penelitian Miradhi dan Juliarsa (2016).

\section{KESIMPULAN}

Penelitian ini dimaksudkan untuk menguji secara empiris pengaruh profitabilitas, solvabilitas, dan ppini audit terhadap audit delay dimoderasi oleh ukuran perusahaan pada perusahaan pertambangan yang terdaftar di Bursa Efek Indonesia (BEI) Periode 20122017. Hasil analisis menunjukkan bahwa profitabilitas berpengaruh negatif terhadap audit delay, solvabilitas dan opini audit tidak berpengaruh terhadap audit delay, ukuran perusahaan tidak mampu memoderasi pengaruh profitabilitas terhadap audit delay, ukuran perusahaan mampu memoderasi pengaruh solvabilitas terhadap audit delay dengan arah posi- tif, dan, ukuran perusahaan tidak mampu memoderasi pengaruh opini audit terhadap audit delay. Berdasarkan hasil penelitian ini diharapkan perusahaan dapat menjaga dan berupaya perusahaan diharapkan dapat menjaga dan tetap berupaya untuk meningkatkan kemampuannya dalam menghasilkan laba, serta dapat memberikan data yang dibutuhkan auditor secara cepat. Agar auditor dapat melaksanakan tugasnya secara efisien. Sehingga tidak mengalami audit delay yang berarti perusahaan mempunyai prospek yang baik dan investor dapat tertarik untuk menanamkan modalnya.

\section{Keterbatasan Penelitian}

(1) Data yang digunakan dalam penelitian ini adalah data sekunder, sehingga peneliti tidak dapat mengendalikan dan mengawasi kemungkinan terjadinya kesalahan dalam perhitungan. (2) Keterbatasan referensi yang peneliti peroleh seperti jurnal pendukung lain untuk mendukung peneliti melakukan penelitian ini, sehingga penelitian ini masih kurang dari sempurna. (3) Penelitian ini hanya menggunakan tiga variabel independen dan satu variable moderasi, sedangkan masih terdapat variabel lain yang mempunyai kemungkinan mempengaruhi audit delay. Oleh karena itu, hasil penelitian ini tidak sepenuhnya dapat digunakan sebagai dasar pengambilan keputusan. (4) Dalam penelitian ini pemilihan sampel hanya terbatas pada perusahaan pertambangan yang terdaftar di Bursa Efek Indonesia (BEI) dan periode pengamatan yang pendek dalam penelitian ini, yaitu hanya enam tahun mulai dari tahun 2012-2017.

\section{Saran}

Penelitian selanjutnya diharapkan dapat menambah variabel independen lain yang dapat mempengaruhi audit delay, seperti umur perusahaan, ukuran perusahaan, ukuran KAP, kualitas auditor, reputasi auditor, dan lain sebagainya.Selain penambahan variable diharapkan dapat memperluas populasi penelitian dan memperpanjang periode penelitian, sehingga hasil penelitian selanjutnya dapat lebih menjelaskan gambaran kondisi yang sesungguhnya. 


\section{DAFTAR PUSTAKA}

Agoes, Soekrisno. 2014. Auditing Petunjuk Praktis Pemeriksaan Oleh Akuntan Publik. Edisi-4 Buku 1. Jakarta: Salemba Empat.

Anshori, Muslich, Badri Munir Sukoco, dan Mikhael Mangihot Napitupulu. 2012. Pencapaian Kinerja Melalui Responsifitas pada Pesaing dengan Moderasi Tensi Persaingan dan Kelonggaran Sumberdaya. Jurnal Manajemen Teori dan Terapan Tahun 1 No. 1, 17-30.

Arens, Alvin A, Randal J. Elder dan Mark S. Beasley. 2015. Auditing dan Jasa Assurance : Pendekatan Terintegrasi. Edisi Kelima Belas- Jilid 1 . Jakarta: Erlangga.

Arumsari, Vivien Fitriana dan Nur Handayani. 2017. Pengaruh Kepemilikan, Profitabilitas, Leverage dan Opini Auditor terhadap Audit Delay. Jurnal Ilmu dan Riset Akuntansi, Vol. 6 No. 4, Hlm. 1364-1379.

Atmojo, Danang Tri dan Darsono. 2017. Analisis Faktor-Faktor Yang Berpengaruh Terhadap Audit Report Lag. Diponegoro Journal of Accounting, Vol. 6 No. 4 Hlm. 1-15.

Darmawan, I Putu Yoga dan Ni Luh Sari Widhiyani. 2017. Pengaruh Ukuran Perusahaan, Kompleksitas Operasi Perusahaan dan Komite Audit Pada Audit Delay. E-Jurnal Akuntansi Universitas Udayana, Vol. 21.1 Hlm. 254-282.

Dewan Standar Akuntansi Keuangan Indonesia. 2017. Standar Akuntansi Keuangan Efektif per 1 Januari 2017. Jakarta : Ikatan Akuntansi Indonesia.

Dewi, Ni Made Wulan Paramitha dan I Dewa Nyoman Wiratmaja. 2017. Pengaruh Profitabilitas Dan Solvabilitas Pada Audit Delay Dengan Ukuran Perusahaan Sebagai Variabel Moderasi. EJurnal Akuntansi Universitas Udayana, Vol. 20.1 Hlm. 409-437.

Eksandy, Arry. 2017. Pengaruh Ukuran Perusahaan, Solvabilitas, Profitabilitas, dan Komite Audit Terhadap Audit Delay.
Jurnal Akuntansi dan Keuangan, Vol. 1 No. 2.

Fahmi, Irham. 2014. Manajemen Keuangan Perusahaan dan Pasar Modal. Jakarta : Mitra Wacana Media

Frazier, Patricia A., Andrew P. Tix, dan Kenneth E. Barron. 2004. Testing Moderator and Mediator Effects in Counseling Psychology Research. Journal of Counseling Psychology Vol. 51 No. 1, 115134.

Ghozali, Imam. 2016. Aplikasi Analasis Multivariate Dengan Program IBM SPSS 21. Edisi-8. Semarang: Universitas Diponegoro

Hastuti, Linda Puji dan Sugeng Santoso. 2017. Pengaruh Solvabilitas, Ukuran KAP, Umur Perusahaan dan Komite Audit terhadap Audit Delay pada Perusahaan Tekstil dan Garment.. Jurnal Penelitian dan Kajian Ilmiah Fakultas Ekonomi Universitas Surakarta, Vol. 15 No.1 Hlm. 27-33.

Hery. 2016. Analisis Laporan Keuangan Integrated and Comprehensive Edition. Jakarta : Grasindo

Kasmir. 2017. Analisis Laporan Keuangan. Depok : PT. Rajagrafindo Persada.

Lapinayanti, Ni Made Mega dan I Ketut Budiartha. 2018. Pengaruh Profitabilitas dan Leverage Pada Audit Delay Dengan Ukuran Perusahaan Sebagai Pemoderasi. E-Jurnal Akuntansi Universitas Udayana, Vol. 23.2 Hal 10661092.

Lestari, Ni Luh Ketut Ayu Sathya dan Made Yenni Latrini. Pengaruh Fee Audit, Ukuran Perusahaan Klien, Ukuran KAP, Dan Opini Auditor Pada Audit Delay. E-Jurnal Akuntansi Universitas Udayana, Vol. 24.1 Hal 422-450.

Messier, William F, Steven M. Glover dan Douglas F. Prawitt. 2014. Jasa Audit dan Assurance: Pendekatan Sistematis. Edisi-8 Buku 1. Jakarta : Salemba Empat.

Miradhi, Made Devi dan Gede Juliarsa. 2016. Ukuran Perusahaan Sebagai Pemoderasi Pengaruh Profitabilitas Dan Opini Auditor Pada Audit Delay. E- 
Jurnal Akuntansi Universitas Udayana, Vol. 16.1 Hal. 388-415.

Muliantari, Ni Putu Indah Ayu dan Made Yenni Latrini. 2017. Ukuran Perusahaan Sebagai Pemoderasi Pengaruh Profitabilitas Dan Financial Distress Terhadap Audit Delay. E-Jurnal Akuntansi Universitas Udayana, Vol. 20.3 Hal. 1875-1903.

Ningsih, I Gusti Ayu Puspita Sari dan Ni Luh Sari Widhiyani. 2015. Pengaruh Ukuran Perusahaan, Laba Operasi, Solvabilitas, Dan Komite Audit Pada Audit Delay. E-Jurnal Akuntansi Universitas Udayana, Vol. 12.3 Hal. 481495.

Peraturan Otoritas Jasa Keuangan Nomor 29/ POJK.04/2016. 2016. Tentang Laporan Tahunan Emiten atau Perusahaan Publik.

Putra, Robby Adytia Putra dan Ita Trisnawati. Faktor-Faktor Yang Mempengaruhi Pergantian Auditor. Jurnal Bisnis dan Akuntansi, Vol.18 No.1 Hal. 94-102.

Priyatno, Duwi. 2016. Belajar Alat Analisis Data dan Cara Pengolahannya dengan SPSS. Yogyakarta: Gava Media

Sugiyono. 2016. Metode Penelitian Kuantitatif, Kualititatif, Dan R\&D. Cetakan Ke23. Bandung: Alfabeta.

Subawa, Putu Gede Ovan dan I Made Pande Dwiana. 2016. Ukuran Perusahaan Sebagai Pemoderasi Pengaruh Opini Auditor, Profitabilitas, Dan Debt To Equity Ratio Terhadap Audit Delay. EJurnal Akuntansi Universitas Udayana, Vol. 14.3 Hal 2278-2306.

Suparsada, Ni Putu Yulianda Damayanti dan IGAM Asri Dwija Putri. 2017. Pengaruh Profitabilitas, Reputasi Auditor, Ukuran Perusahaan dan Kepemilikan Institusional terhadap Audit Delay. EJurnal Akuntansi Universitas Udayana, Vol. 18.1 Hal. 60-87.

Widyastuti, Made Tika dan Ida Bagus Putra Astika. 2017. Pengaruh Ukuran Perusahaan, Kompleksitas Operasi Perusahaan dan Jenis Industri Terhadap Audit Delay. E-Jurnal Akuntansi Universitas Udayana, Vol. 18.2 Hal. 1082-1111.
Wiryakriyana, Anak Gedung Gede dan Ni Luh Sari Widhiyani. 2017. Pengaruh Ukuran Perusahaan, Leverage, Auditor Switching, dan Sistem Pengendalian Internal Pada Audit Delay. E-Jurnal Akuntansi Universitas Udayana, Vol. 19.1 Hal. 771-798 